\title{
Prototipe Jaringan Syaraf Tiruan Multilayer Perceptron Untuk Prediksi Mahasiswa Dropout
}

\author{
Armansyah \\ Program Studi Ilmu Komputer, Fakultas Sains dan Teknologi, \\ Universitas Islam Negeri Sumatera Utara Medan, \\ Jl. IAIN No. 1 Medan, 20235 Telp. (061) 6615683, 6622925, Fax. (061) 6615683 \\ armansyah@uinsu.ac.id
}

\begin{abstract}
Abstrak-- Adanya data mahasiswa yang tidak aktif, yang dipandang sebagai mahasiswa dropout yang secara kuantitas mengalami kenaikan dari tahun ketahun membuat penulis merasa perlu melakukan penelitian ini. Dimana, tingkat mahasiswa dropout merupakan satu indikator penurunan kualitas institusi perguruan tinggi. Jika ini dibiarkan, jumlah mahasiswa dropout akan bertambah bilamana tidak dicari solusinya. Penelitian ini bertujuan memprediksi mahasiswa yang berpotensi putus sekolah dengan pendekatan jaringan syaraf tiruan. Dengan mengamati 13 variabel yang mempengaruhi, dan 1 variabel keluaran yang akan dilatih dengan model multi layer perceptron, diharapkan dapat menghasilkan kinerja prediksi dengan nilai 0 , untuk mahasiswa berpotensi dropout, dan 1 untuk mahasiswa yang tetap melanjut hingga akhir, dengan menunjukkan hasil komputasi tingkat akurasi setidaknya 96,90\% dan tingkat error yang rendah.
\end{abstract}

Kata kunci : Prediksi, Dropout, Jaringan Syaraf Tiruan, Multi-Layer Perceptron.

\begin{abstract}
The existence of data on inactive students, who are seen as dropout students whose quantity has increased from year to year makes the author feel the need to do this research. Where, the dropout rate is an indicator of a decline in the quality of higher education institutions. If this is allowed, the number of dropout students will increase if a solution is not found. This study aims to predict students who have the potential to drop out of school using an artificial neural network approach. By observing 13 variables that influence, and 1 output variable that will be trained with a multi-layer perceptron model, it is expected to produce a predictive performance with a value of 0 , for students who have the potential to drop out, and 1 for students who continue to the end, by showing the computational results of the level of accuracy. at least $96.90 \%$ and a low error rate.
\end{abstract}

Keywords: Prediction, Dropout, Artificial Neural Network, Multi-Layer Perceptron.

\section{Pendahuluan}

Pendaftaran mahasiswa baru Program Studi Ilmu Komputer dari tahun ketahun selalu dalam kategori baik. Hal ini terlihat dari daftar pelamar yang terhitung dari tahun berdiri sampai tahun terakhir penerimaan mahasiswa baru, yang jika ditilik dari angka-angka dan grafiknya, tampak bahwa Program Studi Ilmu Komputer Universitas Islam Negeri (UIN) Sumatera Utara, mengalami kenaikan. Meskipun sepanjang tahun 2018-2020 grafik penerimaan mahasiswa baru menunjukkan pergerakan yang cukup stabil, namun, jika dibandingkan dengan empat Program Studi di Fakultas yang sama seperti Program Studi Matematika, Fisika, Biologi, Sistem Informasi, dan juga Program Studi di Fakultas lainnya, Program Studi Ilmu Komputer menunjukkan keberadaannya sebagai Program Studi yang paling diminati oleh pelamar dari berbagai daerah di provisi ini (Sumatera Utara). Dengan kata lain, Program Studi Ilmu Komputer merupakan Program Studi yang masih diminati setidaknya dalam beberapa tahun ke depan, dibandingkan dengan berbagai tawaran Program Studi yang ada di delapan fakultas UIN Sumatera Utara Medan.

Meskipun grafik penerimaan mahasiswa baru menunjukkan kenaikan dan stabil pada beberapa tahun terakhir seperti yang ditunjukkan pada gambar 1, namun ternyata jumlah angka putus sekolah (dropout) juga menunjukkan kuantitas juga tinggi seperti yang ditampilkan pada tabel 1. Di dalam hand-out yang diterbitkan oleh [1], dropout dimaknai dengan keluar atau berhentinya peserta didik sebelum waktunya atau sebelum lulus. Mahasiswa dropout umumnya keluar tanpa informasi, dengan kata lain keluar tanpa membawa bukti administrasi yang jelas. Secara kuantitas, mahasiswa dropout pada Program Studi Ilmu Komputer di UIN Sumatera Utara dipandang cukup tinggi. Berdasarkan pengamatan penulis, setidaknya ada $5 \%$ mahasiswa tidak benar-benar menyelesaikan pendaftarannya sampai selesai, sisanya terdapat setidaknya $7 \%$ mahasiswa menyusul berhenti dari pendidikannya pada tingkat dua, dan hingga tahun ketiga pendidikannya, ada sekitar 15-an\% mahasiswa dari setiap angkatan memutuskan tidak lagi melanjutkan pendidikannya. Jika 15-an\% dari setiap angkatan keluar atau berhenti ditengah pendidikannya, ini dipandang cukup tinggi. Keadaan ini bukan suatu yang menggemberikan dan dapat dipandang suatu masalah yang cukup serius. Permasalahan ini perlu dicarikan solusinya, dengan setidaknya melalui prediksi tingkat dropout mahasiswa. Upaya prediksi mahasiswa dropout tentu tidak sepenuhnya dapat menyelesaikan masalah, namun, melalui pradiksi dengan melibatkan faktor-faktor yang mempengaruhi dapat memberikan informasi yang berarti untuk mereduksi 
mahasiswa yang memiliki potensi dropout, dengan cara misalnya menyelenggaran bimbingan konseling lebih awal atau pendampingan yang kontinu terhadap mahasiswa-mahasiswa yang terjaring sebagai mahasiswa yang berpotensi putus sekolah.

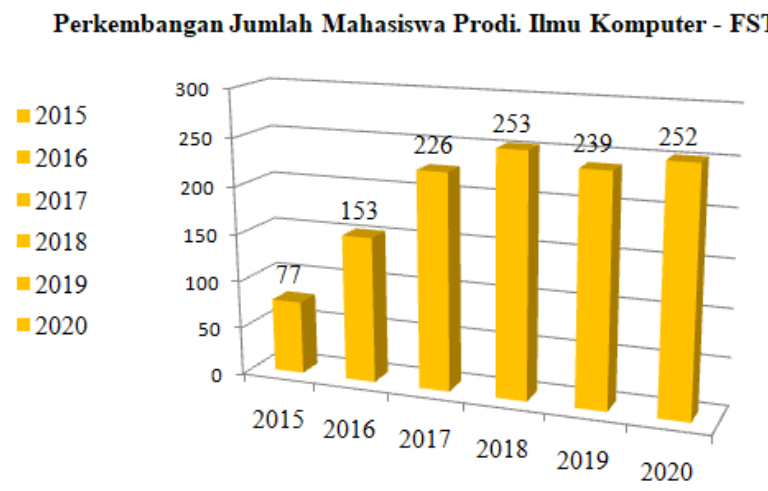

Gambar 1. Grafik Penerimaan Mahasiswa Baru[2]

\begin{tabular}{|l|c|c|c|}
\hline Angkatan & Mahasiswa Baru & Jumlah Droput & Persen Dropout \\
\hline 2015 & 77 & 13 & 16,88 \\
\hline 2016 & 153 & 31 & 20,26 \\
\hline 2017 & 226 & 27 & 11,96 \\
\hline 2018 & 253 & 40 & 15,81 \\
\hline 2019 & 239 & 16 & 6,69 \\
\hline
\end{tabular}

Tabel 1. Tabel Mahasiswa Dropout (sia.uinsu.ac.id, 2021)

Prediksi mahasiswa putus sekolah sudah sering dilakukan oleh banyak peneliti menggunakan teknik machine learning dan Jaringan Syaraf Tiruan dengan berbagai metode, dengan tujuan untuk mencari faktor yang mempengaruhinya, atau untuk tujuan menyeselaikan permasalahan tingginya tingkat mahasiswa dropout. Ada banyak faktor yang menyebabkan tingginya angka dropout. Dalam jurnal yang ditulis oleh [3], terdapat lima faktor utama yang menyebabkan siswa putus sekolah diantaranya faktor : motivasi, kondisi, intelektual, ekonomi dan peluang. Selain itu, jenis kelamin, karakter pribadi, keluaraga, dan beberapa lain yang digunakan oleh Haidar, Mingjie, dan Mayra juga memengaruhi mahasiswa dropout [4][5][6]. Tidak hanya penelitian terkait pencarian faktor penyebab, penelitian yang menggunakan teknik machine learning juga dilakukan, seperti yang menggunakan algoritma ID3 dan C.45[7][8]. Dalam penelitiannya, mereka menggunakan Indeks Prestasi Mahasiswa (IPK), jarak tempat tinggal ke kampus, lama masa studi, status bekerja atau tidak, status berkeluarga atau lajang, dan kelancaran pembiayaan sebagai variabel masukkannya. Dari penelitiannya itu algoritma ID3 menunjukkan akurasi 95,17\% sementara C.45 memberikan akurasi 96,45\%. Selain mereka, [9] juga melakukan penelitian yang sama terhadap mahasiswa di Sichuan Open University yang menerapkan pembelajaran e-learning menggunakan tiga algoritma seperti Jaringan Syaraf Tiruan(JST), Pohon Keputusan(C5.0), dan, Jaringan Bayesian(Bayes). Mereka menggunakan dua atribut yakni karakteristik pribadi siswa, dan kinerja akademik serta menyatakan bahwa, prestasi akademik bukan merupakan faktor yang mempengaruhi putus sekolah berdasarkan model Tinto dan Kember yang telah disetujui dan telah dibuktikan secara empiris oleh banyak periset. Mereka, dalam risetnya menginformasikan algoritma C5.0 dan JST cukup efektif dalam melakukan predikti putus sekolah dengan akurasi masing-masing secara berurutan yakni C5.0 94,63\%, JST 93,97\%, dan Bayes 93,92\%.

Selain itu, [10] juga menggunakan machine learning JST dalam melakukan penelitian yang sama untuk mahasiswa bidang Administrasi dan Ilmu Pengetahuan Karir Manusia pada Public University of Ecuador. Mereka menggunakan metode Multilayer Perceptrom (MLP) dan Radial Basis Function(RBF) dan menggunakan atribut data demografi, perilaku mahasiswa, metodologi pendidikan universitas, proses akademik dan sosial ekonomi mahasiswa, yang dibagi dalam 11 variabel masukan dan 1 output. Simpulan penelitian mereka melaporkan bahwa kedua metode tersebut, juga sangat efektif dengan tingkat akurasi masing-masing 96,3\% untuk MLP dan 96,8 untul RBF.

Penelitian ini bertujuan untuk menyajikan prototipe JST untuk memprediksi tingkat dropout pada Program Studi Ilmu Komputer, dengan menggunakan beberapa atribut yang terkait dekat dengan faktor yang 
mempengaruhi dropout, merujuk kepada penelitian-penelitian terdahulu. Hasil pelatihan data dan pengujiannya akan dilaporkan setelah penelitian ini selesai dilaksanakan. Metode yang akan digunakan adalah JST Multilayer Perceptron yang melibatkan beberapa atribut masukan seperti karakter pribadi, motivasi, finansial dan kelancaran biaya pendidikan, lingkungan keluarga, pendidikan orangtua, jenis kelamin, jarak antara rumah dengan kampus, pelayanan akademik, tenaga pembimbing (dosen), hubungan kedekatan dengan pembimbing, perguruan tinggi dan kurikulumnya, lingkungan bermain atau pertemanan, serta performa atau sikap belajar.

\section{Tinjauan Pustaka}

Jaringan Syaraf Tiruan (JST) merupakan pemodelan pembelajaran mesin (Machine Learning), yang menggunakan pendekatan belajar secara terbimbing (supervised) dan pendekatan belajar secara tidak terbimbing (unsupervised)[11]. Kemampuan JST dalam mempelajari data, membuatnya mampu melaksanakan tugas-tugas seperti pengenalan pola, klasifikasi, prediksi, pengolahan sinyal dan tugas-tugal lainnya, seperti yang disampaikan oleh [12]. Dalam penelitian ini, JST dimodelkan untuk melakukan prediksi terhadap data. Prediksi, merupakan ramalan atau prakiraan, dimana upaya tersebut dilakukan secara komputasi dengan mencocokkan antara data masukan dengan data target, seperti telah dilakukan pada penelitian pada 2019 lalu[13]. Dalam penelitiannya, berbagai data kuesioner di komputasikan dengan JST Backpropagation untuk memprediksi kemampuan mahasiswa dalam mata kuliah pemrograman komputer.

Ada banyak metode JST, perceptron merupakan model yang paling lama, yang mampu dalam melakukan kinerja prediksi dan klasifikasi, khususnya untuk klasifikasi linear. Perceptron terbagi dalam single layer dan multi layer. Single layer merupakan arsitektur pengklasifikasian linear, sementara multi layer merupakan arsitektur pengklasifikasian non-linear. Prinsip kerja multi layer terdiri dari dua fase dan penyesuaian bobot, yakni fase maju (forward), fase mundur (backward). Diantara fase maju dan mundur terjadi proses komputasi, yakni, pada fase maju, jaringan akan menghitung keluaran di lapisan terdalam pertama, lalu menerapkan keluaran pada lapisan tersembunyi tersebut sebagai data masukkan untuk lapisan tersembunyi selanjutnya, atau untuk lapisan paling luar (akhir). Apabila keluaran di lapisan akhir, masih menunjukkan tingkat error yang masih tinggi, maka komputasi akan berlaku mundur untuk mencari faktor bobot yang salah. Dengan kata lain, pada fase mundur, jaringan akan melakukan perubahan terhadap bobot di setiap lapisan, lalu bermaju kembali ketika semua bobot jaringan di semua lapisan telah diperbaharui[12].

Dalam penelitian ini arsitektur JST MLP digunakan untuk memprediksi mahasiswa yang berpotensi putus sekolah atau dropout dimana feature diambil dari data kuesioner. Dropout adalah siswa meninggalkan sekolah sebelum menyelesaikan masa belajar secara keseluruhan yang telah ditetapkan sekolah yang bersangkutan[14]. Ada banyak faktor yang menyebab pelajar memutuskan berhenti sekolah. Faktor penyebab ini juga berbeda untuk jenjang pendidikan dan teknis pembelajarannya (dalam jaringan atau tatap muka). Diantara faktor yang mempengaruhi putus sekolah, [15] menuliskan dalam laporannya, diantaranya faktor lingkungan keluarga, lingkungan masyarakat, lingkungan sekolah, minat dan ekonomi merupakan faktor yang sering terjadi.

\section{Metode Penelitian}

Ide dari penelitian ini adalah adanya angka dropout mahasiswa yang terus bertambah dari tahun ketahun, yang, apabila permasalahan ini tidak segera ditanggulangi akan menambah grafik kenaikan kuantitas mahasiswa dropout. Sementara tingginya tingkat mahasiswa dropout merupakan indikator penurunan kualitas perguruan tinggi atau lembaga pendidikan. Terkait dengan ide dasar itu, penulis mencoba menempuh beberapa upaya dalam penelitian, yang tahapan-tahapannya disajikan sebagai berikut :

\subsection{Studi Pustaka}

Untuk menghimpun berbagai informasi yang menyangkut permasalahan penelitian, penulis mengumpulkan referensi yang berakitan dengan faktor-faktor yang melatarbelakangi mahasiswa memutuskan untuk berhenti atau keluar dari pendidikannya, serta referensi yang merujuk kepada teknik machine learning yang mampu melakukan pembelajaran terhadap data prediksi mahasiswa dropout.

\subsection{Pengumpulan data}

Penelitian dengan teknik machine learning, koleksi data merupakan komponen utama. Karena, suatu mesin, dalam hal ini program komputer dapat melakukan prediksi apabila ada koleksi data yang terpola dengan benar. Untuk memperoleh data yang dimaksud sebagai kumpulan data yang terpola itu, maka dibutuhkan langkah tepat. Dalam penelitian ini, pengumpulan data dilakukan secara online menggunakan aplikasi google form yang dapat digunakan secara bebas, dengan menggunakan instrumen kuesioner yang menyangkut berbagai hal yang berkaitan erat atau yang memiliki relevansi yang kuat sebagai faktor mahasiswa memutuskan untuk berhenti dari pendidikannya. Dalam pengumpulan datanya, kuesioner akan disebar kepada semua mahasiswa aktif pada semester mendatang (Gasal 2021/2022) atau setelah artikel ini diterbitkan. 


\subsection{Pemrosesan data}

Dalam komputasi yang menggunakan teknik machine learning, pemrosesan data adalah langkah mengolah data yang dilakukan secara komputerisasi dengan pemodelan tertentu, serta dengan pendekatan pembelajaran tersupervisi ataupun pembelajaran tidak tersupervisi. Pengolahan data ini berlangsung pada tahap pelatihan data dan pengujian data. Tahap pelatihan data adalah tahapan dimana machine (aplikasi) menerapkan algoritma untuk melakukan pengenalan terhadap target yang hendak dicapai. Target data ini dipandang sebagai guru pada pendekatan belajar tersupervisi. Multi Layer Perceptron (MLP) adalah salah satu pemodelan JST yang menerapkan pendekatan belajar tersupervisi. Dengan metode MLP ini, penelitian ini akan di terapkan untuk mengenali data-data masukan yang telah dikoleksi dari kuesioner untuk memilah output yang masuk dalam klasifikasi mahasiswa berpotensi lulus, dan mahasiswa berpotensi dropout.

3.4. Analisis data

Data keluaran dari proses palatihan dan pengujian akan disajikan dalam uraian tabel kesimpulan, yang menguraikan peserta-peserta yang dipandang sebagai mahasiswa yang kuat bersemangat hingga lulus, dan mahasiswa yang memiliki potensi dropout. Hal ini perlu dilakukan untuk memberikan kemudahan dalam memahami data yang telah diolah, serta memberikan gambaran keberhasilan metode yang digunakan.

3.5. Kesimpulan

Uraian kesimpulan merupakan uraian yang menjabarkan keberhasilan metode. Dimana, keberhasilan metode akan ditunjukkan dalam bentuk tingkat akurasi serta pengukuran terhadap relevansi antara variabel masukkan dengan variabel keluaran.

\section{Hasil dan Pembahasan}

\subsection{Hasil}

Penelitian ini masih dalam tahap perencanaan, dengan demikian penulis belum dapat menyajikan hasil penelitian. Pengumpulan data akan dilakukan pada semester mendatang dan akan dilakukan pelatihan dan pengujian data setelahnya. Laporan akan disajikan sesegera mungkin setelah pelatihan dan pengujian data dilakukan.

\subsection{Pembahasan}

Permasalahan yang ada pada penelitian ini, dirumuskan dengan melakukan prediksi terhadap seluruh mahasiswa yang aktif yang diwakili oleh data kuesioner. Sementara metode pemrosesan data dengan teknik machine learning dipilih berdasarkan tingkat akurasinya yang baik. Dan Jaringan Syaraf Tiruan Multi Layer Perceptron (JST MLP) dipandang sesuai dan akan digunakan pada penelitian ini. Dalam melakukan pelatihan dan pengujian data, nilai 0 akan digunakan untuk mewakili mahasiswa yang memiliki potensi dropout, sementara nilai 1 untuk mewakili mahasiswa yang tetap melanjut hingga selesai dari pendidikannya. Untuk memperoleh keputusan itu, JST MLP akan menerima (sejumlah feature) masukan yang akan dijabarkan secara rinci sebagai berikut :

1) Karakter pribadi

Karakter indentik dengan moral atau akhlak, yang mampu memengaruhi kondisi pikiran, perasaan, ucapan, dan perilaku manusia yang terkait dengan nilai-nilai baik dan buruk [16]. Variabel ini mewakili jawaban kuesioner yang berkaitan sikap tempramen, ketenangan dalam berfikir, berbicara, dan perilaku lain yang mencerminkan kepribadian. Jawaban 'tidak' dan 'ya' akan diwakili dengan nilai 0 dan 1.

2) Motivasi

Motivasi merupakan dorongan yang timbul pada diri seseorang secara sadar atau tidak sadar untuk melakukan suatu tindakan dengan tujuan tertentu. Variabel ini mewakili jawaban kuesioner yang berkaitan dengan dorongan yang timbul dari dalam hati untuk menghadapi semua rintangan untuk melanjutkan pendidikan sampai akhir. Jawaban 'tidak' dan 'ya' akan diwakili dengan nilai 0 dan 1.

3) Finansial

Variabel ini akan mewakili jawaban kuesioner yang menggambar kondisi finansial baik dan kurang baik. Sementara kelancaran pembiayaan dipengaruhi oleh kondisi finalsial yang baik. Varibel ini mewakili jawaban kuesioner 'tidak' dan 'ya' dengan nilai 0 dan 1 terhadap pertanyaan ukuran finansial mahasiswa.

4) Lingkungan keluarga

Variabel ini mewakili jawaban pertanyaan kuesioner yang menggambarkan keharmonisan lingkungan keluarga dengan jawaban 'tidak' dan 'ya', yang direpresentasikan dengan nilai 0 dan 1.

5) Pendidikan orang tua

Variabel ini mewakili jawaban pertanyaan kuesioner untuk menggambarkan pendidikan orangtua. Dimana, tingginya pendidikan orangtua merupakan indikator positif terhadap kemajuan dan sikap diri seorang anak. Dengan tingginya pendidikan orangtua, dorongan terhadap anak menunjukkan nilai positif pula. Jawaban kuesioner untuk variabel ini juga 'tidak' dan 'ya' dengan nilai 0 dan 1. 
6) Jenis kelamin

Menurut [4], jenis kelamin pria lebih cepat dalam memutuskan untuk keluar dari pendidikannya ketika mengalami suatu masalah yang rumit. Untuk menggunakan variabel ini jawaban kesioner berupa 'pria' dan 'wanita' yang diwakili dengan nilai 0 dan 1 .

7) Jarak tempuh

Jarak tempuh antara tempat tinggal menuju kampus memengaruhi semangat mahasiswa, semakin jauh jarak tempuh akan berdampak pula pada unjuk kerja atau performa mahasiswa dalam mengikuti perkuliahan. Sehingga ini dapat dipertimbangkan menjadi suatu variabel masukan. Variabel ini akan dipilih dengan jawaban 'jauh' dan 'tidak jauh' yang diwakili dengan nilai 0 dan 1.

8) Pelayanan akademik

Tidak bisa difungkiri bahwa setiap mahasiswa akan berhubungan langsung dengan petugas pelayanan akademik. Petugas yang ramah, atau menyenangkan berdampak positif bagi semangat mahasiswa dalam penjalani pendidikannya. Variabel ini menentukan jawaban untuk pertanyaan kuesioner berupa "tidak ramah" dan "ramah" atau "tidak menyenangkan" dan "menyenangkan" yang juga diwakili dengan nilai 0 dan 1.

9) Tenaga pembimbing

Kualitas tenaga pembimbing (dosen) yang baik mampu meningkatkan semangat dan kesungguhan, serta mampu memberikan inspirasi dan motivasi kepada mahasiswa. Variabel ini digunakan dan menyediakan jawaban pertanyaan kuesioner berupakan "berkualitas rendah" dan "berkualitas tinggi" yang diwakili dengan nilai 0 dan nilai 1 .

10) Hubungan kedekatan dengan pembimbing

Sering kali mahasiswa menutup diri terhadap permasalahan yang mereka hadapi. Tidak sedikit mahasiswa jesteru menemukan solusi yang buruk, alih-alih mereka terjebak pada situasi yang tidak bisa mereka selesaikan sendiri. Kondisi mahasiswa yang demikian membutuhkan pendampingan khususnya oleh Pembimbing Akademis. Sehingga ini verlu dipertimbangkan menjadi variabel yang untuk permasalahan dropout. Variabel ini digunakan sebagai jawaban pertanyaan kuesioner berupa "tidak dekat" dan "dekat" dengan Pembimbing Akademis yang direpresentasikan dengan nilai 0 dan 1.

11) Perguruan tinggi

Pada umumnya, mahasiswa memilih perguruan tinggi berdasarkan ketertarikannya. Ini berkaitan dengan pemahaman awal yang mereka ketahui tentang perguruan tinggi yang akan mereka pilih. Kebanyakan mahasiswa memilih berdasarkan status, kualitas, akreditasi perguruan tingginya. Ini juga merupakan indikator yang cukup besar pengaruhnya untuk apakah mahasiswa tetap bertahan atau meninggalkan universitas karena alasan bahwa status perguruan tinggi "berpopularitas rendah" atau yang "memiliki popularitas yang baik". Alasan tersebut juga merupakan faktor yang mempengaruhi. Dalam penelitian ini, perguruan tinggi perlu dipandang sebagai variabel masukkan yang memberikan nilai 0 untuk status perpopularitas rendah, dan 1 untuk status perguruan tinggi berpopularitas.

12) Lingkungan bermain atau pertemanan

Lingkungan pertemanan yang baik mampu memberikan arah yang positif, sebaliknya justeru memberikan dampak buruk bagi kelangsungan pendidikan mahasiswa. Variabel sangat memengaruhi, dan dipandang perlu menggunakannya. Variabel ini memberikan jawaban pertanyaan kuesioner berupa lingkungan pertemanan "tidak baik" dan lingkungan pertemanan "baik". Variabel ini di wakili dengan jawaban bernilai 0 dan 1.

13) Performa atau sikap belajar

Performa atau sikap belajar mahasiswa bisa ditunjukan dalam bentuk sikap sungguh--sungguh, rajin, tekun, atau justeru hura-hura atau bermalas-malasan. Tidak sedikit mahasiswa yang berhenti ditengah pendidikannya karena menampilkan unjuk kerja atau performa yang kurang baik. Ini perlu dirumuskan karena merupakan faktor yang memengaruhi mahasiswa berpotensi dropout. Variabel ini akan menyajikan jawaban berupa "tidak baik" dan "baik" yang akan diwakili dengan nilai 0 dan 1.

Dari uraian deskripsi feature atau variabel masukkan yang ditampilkan diatas, maka dapat disederhanakan dalam bentuk tabel berikut :

Tabel 2 Deskripsi Variabel Masukan

\begin{tabular}{|l|l|l|}
\hline Variabel & Deskripsi & Tipe \\
\hline
\end{tabular}




\begin{tabular}{|c|l|l|}
\hline X1 & Karakter Pribadi & Binary \\
\hline X2 & Motivasi & Binary \\
\hline X3 & Finansial dan kelancaran biaya pendidikan & Binary \\
\hline X4 & Lingkungan keluarga & Binary \\
\hline X5 & Pendidikan orangtua & Binary \\
\hline X6 & Jenis kelamin & Binary \\
\hline X7 & Jarak tempuh & Binary \\
\hline X8 & Pelayanan akademik & Binary \\
\hline X9 & Tenaga pembimbing (dosen) & Binary \\
\hline X10 & Hubungan kedekatan dengan pembimbing & Binary \\
\hline X11 & Perguruan tinggi dan kurikulumnya & Binary \\
\hline X12 & Lingkungan bermain atau pertemanan & Binary \\
\hline X13 & Performa atau sikap belajar. & Binary \\
\hline Prediksi & $\begin{array}{l}\text { Prediksi mahasiswa Dropout (0), dan prediksi } \\
\text { mahasiswa melanjut hingga lulus (1) }\end{array}$ & Binary \\
\hline & & \\
\hline
\end{tabular}

Berdasarkan pada tabel 2, maka disusunlah arsitektur Jaringan Syaraf Tiruan dengan merujuk kepada Multi Layer Perceptron seperti yang ditunjukkan pada gambar berikut :

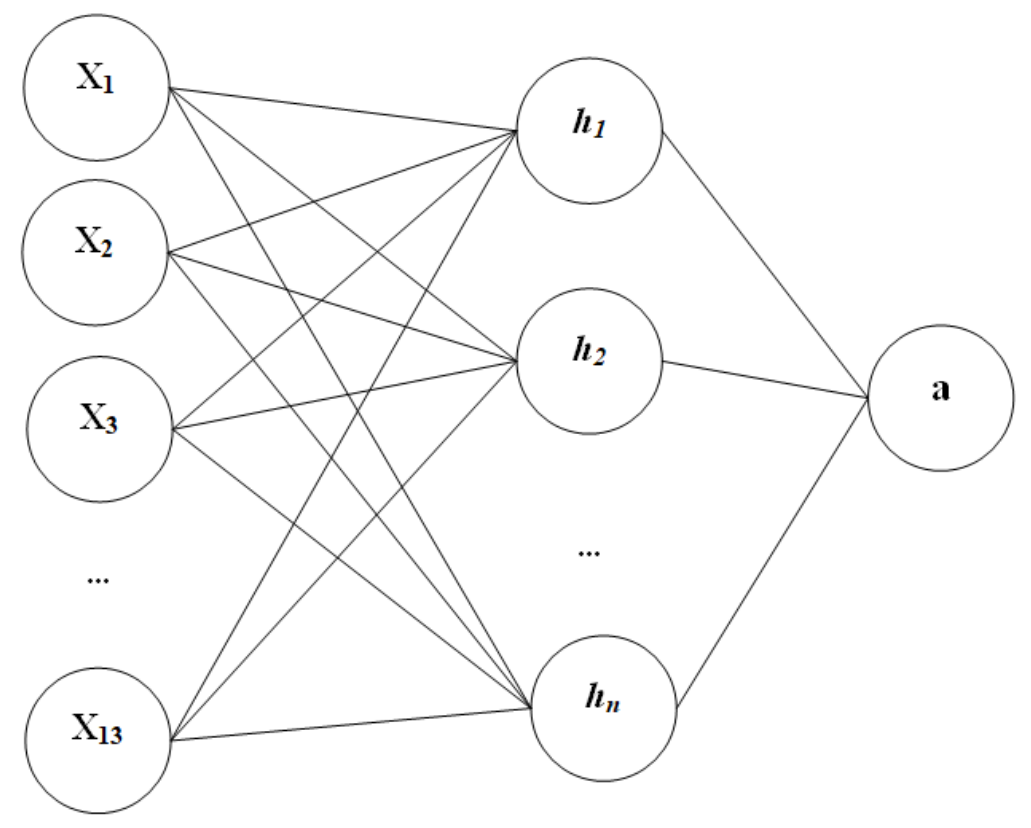

Gambar 2 Arsitektur JST MLP

\section{Kesimpulan}

Penelitian ini masih tahap perencanaan dan akan dilaksanakan pada semerter gasal 2021/2022 mendatang. Hasil penelitiannya akan dilaporkan sesegera mungkin setelah tahapan eksperimen terhadap data pelatihan dan pengujian dilakukan. Adapun aplikasi akan menghasilkan nilai kinerja prediksi 0 dan 1 menggunakan beberapa feature masukan yakni, karakter pribasi, motivasi, finansial, lingkungan keluarga, pendidikan orangtua, jenis kelamin, jarak tempuh, pelayanan akademik, tenaga pembimbing, hubungan kedekatan dengan pembimbing, pergutuan tinggi, lingkungan bermain dan pertemanan, dan performa atau sikap belajar. Jika merujuk kepada riset-riset terkait yang digunakan dalam referensi ini, penulis meyakini hasil prediksi mendapatkan akurasi yang tinggi dalam menghasilkan nilai prediksi 0, untuk mahasiswa yang berpotensi dropout, dan prediksi nilai 1 untuk mahasiswa yang kuat melanjut hingga akhir pendidikannya. 


\section{Daftar Pustaka}

[1] Fakultas Ilmu Pendidikan UM, "Mutasi dan dropout," 2015.

[2] K. Pengantar, "BUKU PROFIL PROGRAM STUDI ILMU TEKNOLOGI UIN SUMATERA UTARA MEDAN TAHUN 2017," 2017.

[3] T. Ali, "Analisis Indikator Kegagalan Siswa Dalam Menempuh Pendidikan Di Sekolah,” J. Ilm. Pendidik. dan Pembelajaran(JIPP), vol. Vol 4, No, pp. 537-545, 2020.

[4] I. F. Yang, B. Dengan, M. Putus, K. Di, and I. P. B. Angkatan, "Identifikasi Faktor-Faktor Yang Berhubungan Dengan Mahasiswa Putus Kuliah Di Ipb Angkatan 2008 Menggunakan Analisis Survival," Xplore J. Stat., vol. 1, no. 2, pp. 2-7, 2013.

[5] N. B. Şara, R. Halland, C. Igel, and S. Alstrup, "High-school dropout prediction using machine learning: A Danish large-scale study," 23rd Eur. Symp. Artif. Neural Networks, Comput. Intell. Mach. Learn. ESANN 2015 - Proc., no. November 2014, pp. 319-324, 2015.

[6] A. S, A. Ahmad, and R. Ridfah, "Penerimaan Diri Pada Mahasiswa Drop Out," Psikoislamedia J. Psikol., vol. 2, no. 1, p. 1, 2017.

[7] L. R. Haidar, E. Sediyono, and A. Iriani, "ANALISA PREDIKSI MAHASISWA DROP OUT MENGGUNAKAN METODE DECISION TREE DENGAN ALGORITMA ID3 dan C4.5," $J$. Transform., vol. 17, no. 2, p. 97, 2020.

[8] R. Noviani and S. Sulindawaty, "Sistem Pakar Mendiagnosa Gizi Buruk Pada Balita Menggunakan Teorema Bayes," J. Nas. Komputasi dan Teknol. Inf., vol. 3, no. 2, pp. 163-169, 2020.

[9] M. Tan and P. Shao, "Prediction of student dropout in E-learning program through the use of machine learning method," Int. J. Emerg. Technol. Learn., vol. 10, no. 1, pp. 11-17, 2015.

[10] M. Alban and D. Mauricio, "Neural networks to predict dropout at the universities," Int. J. Mach. Learn. Comput., vol. 9, no. 2, pp. 149-153, 2019.

[11] S. Susmanto, Z. Zulfan, and M. Munawir, "Sistem Penerapan Fuzzy Multi Attribute Decision Making (MADM) Dalam Mendukung Keputusan Untuk Menentukan Lulusan Terbaik Pada Sekolah Tinggi Teknik Poliprofesi Medan,” J. Nas. Komputasi dan Teknol. Inf., vol. 1, no. 1, 2018.

[12] K. Pengantar, "Modul 1 Pengantar Jaringan Syaraf Tiruan," 1943.

[13] B. Keluarga, T. Tinggal, G. Syahputra, and M. I. Perangin-angin, "Analisis Kemampuan Akademik Mahasiswa Berdasarkan Latar Dengan Jaringan Syaraf Tiruan Backpropagation,” vol. 19, no. 1, pp. 75-85, 2020.

[14] J. D. W. Kahl et al., "No 主観的健康感を中心とした在宅高齢者における 健康関連指標に関す る共分散構造分析Title,” Time, vol. 6, no. 3, p. 198, 2019.

[15] T. Kamsihyati, S. Sutomo, and S. FS, "Kajian Faktor-Faktor Penyebab Anak Putus Sekolah di Desa Jangrana Kecamatan Kesugihan Kabupaten Cilacap,” Geo Edukasi, vol. 5, no. 1, pp. 16-21, 2016.

[16] Samrin, "Pendidikan Karakter (Sebuah Pendekatan Nilai)," J. Al-Ta'dib, vol. 9, no. 1, pp. 120-143, 2016. 